\title{
Scaffolding and interventions between students and teachers in a Learning Design Sequence
}

\author{
Teachers' scaffolding and interventions
}

\author{
Eva Edman Stålbrandt \\ Annika Hössjer
}

\begin{abstract}
The aims of this paper are to develop knowledge about scaffolding when students in Swedish schools use digital educational material and to investigate what the main focus is in teachers' interventions during a Learning Design Sequence (LDS), based on a socio-cultural perspective. The results indicate that scaffolding were most common in the primary transformation unit and the most frequent type was procedural scaffolding, although all types of scaffolds; conceptual, metacognitive, procedural, strategic, affective and technical scaffolding occurred in all parts of a learning design sequence. In this study most of the teachers and students, think that using digital educational material requires more and other forms of scaffolding and concerning teacher interventions teachers interact both supportively and restrictively according to students' learning process. Reasons for that are connected to the content of the intervention and whether teachers intervene together with the students or not.
\end{abstract}

Keywords: Technology; Scaffolding; Knowledge.

\section{Estruturas de apoio e intervenção entre estudantes e professores num Modelo de Aprendizagem Sequenciada (MAS)}

\section{Resumo}

O objetivo desse artigo é conhecer as Estruturas Educacionais de Apoio (EEA) quando alunos em escolas suecas utilizam material educacional digital e investigar qual é o principal foco nas intervenções dos professores durante um Modelo de Aprendizagem Seqüenciada (MAS), baseado numa perspectiva sócio-cultural. Os resultados indicam que as EEA foram mais comuns nas unidades de transformação primárias e o tipo mais freqüente foi a EEA de procedimento, embora todos os tipos tenham sido identificados - conceitual, metacognitiva, processual, estratégica e afetiva. EEA técnica ocorreu em todas as etapas do MAS. Nesse estudo a maioria dos professores e alunos, pensam que para utilizar material de educação digital é necessário outras formas de MAS. Além disso, de acordo com o processo de aprendizado dos alunos, as intervenções dos professores foram consideradas tanto de apoio quanto de restrição. Os motivos para isso estão relacionados ao conteúdo das intervenções e se os professores intervem junto aos alunos ou não. Palavras chave: Tecnologia; Estruturas educacionais de apoio; Conhecimento.

\section{Estructuras de apoyo e intervención entre estudiantes y profesores en un Modelo de Aprendizaje Secuencial (MAS)}

\section{Resumen}

El objetivo de este artículo es conocer las Estructuras Educacionales de Apoyo (EEA) cuando alumnos en escuelas suecas utilizan material educacional digital, e investigar cual es el foco principal en las intervenciones de los profesores durante un Modelo de Aprendizaje Secuencial (MAS), apoyado en una perspectiva socio-cultural. Los resultados indican que las EEA fueron más comunes en las unidades de transformación primarias y el tipo más frecuente fue la EEA de procedimiento, pese a que todos los tipos fueron identificados - conceptual, metacognitiva, procesal, estratégica y afectiva. EEA técnica ocurrió en todas las etapas del MAS. En este estudio la mayor parte de los profesores y de los alumnos piensan que para utilizar material de educación digital son necesarias otras formas de MAS. Además de eso, de acuerdo con el proceso de aprendizaje de los alumnos, las intervenciones de los profesores fueron consideradas tanto de apoyo como de restricción. Los motivos para eso están relacionados al contenido de las intervenciones y a si los profesores intervienen junto a los alumnos o no.

Palabras clave: Tecnología; Estructuras educacionales de apoyo; Conocimiento. 


\section{Introduction}

This paper is written within the research project, "Digital Teaching Aids and Learning Design Sequence in Swedish Schools - Users' Perspective". The study is in the research field of ICT and it is based at the Stockholm Institute of Education. The project's purpose is to deepen the understanding of how digital media are used as a resource for learning in education. The project runs for three years, from the year of 2004 to 2007 and is led by professor Staffan Selander, financed by The Swedish Knowledge foundation.

Ten schools were selected by their active use of ICT. Students were from 6 to 19 years old and they were observed in different subjects. Different researchers have different research questions concerning for example communication, interaction, the digital tool and subject integration with ICT. In this paper we only present two researchers' different questions, on one hand scaffolding and on the other hand teachers' interventions. The two groups of questions were not linked together from the beginning, we just use the same material in one case. Three schools in the suburbs of Stockholm were chosen from the material. The subjects which were included in the Learning Design Sequence in these three schools were Swedish language, Music, ICT, Home economics and Social science. The students' were 8 , 13, 14 and 17 years old.

The main questions for scaffolding: in this study are:

- What kinds of scaffolding occur when students use digital educational material and where in a learning design sequence do they occur?

- Do students understand the same phenomena of scaffolding as teachers?

- Do students and teachers believe that schoolwork with digital educational material demands more, less or other kinds of scaffolding for learning?

The main questions for teachers' interventions in this study are:

- What is the main focus of the teacher intervention?
- Are teacher interventions supportive or restrictive for students' learning process?

\section{Theoretical framework}

The theoretical framework is primarily based on socio-cultural perspective. Vygotsky's socio-cultural theory of learning points out that human intelligence stems from the culture we are living in. Human cognition occurs in the first place on a social level in interaction with other human beings and thereafter inside the individual (Vygotsky, 1978). Learning is a process of engagement and activity together with other people where actions and thinking are situated. The process, form and content are all merged within activities, where communication is important. These activities are interdisciplinary (Lave \& Wenger, 2003; Säljö, 2005).

In the socio-cultural perspective the artefact is central. Pupils' thinking is thought to be intimate connected to the artefacts they are using. This is shown in the interaction between pupil and artefact where the pupil for example often can manage complicated actions without being able to verbalize them, which is a common scenario in the material. Säljö means that it is useless trying to understand what goes on in one pupils head - instead we try to understand learning in the interaction between pupils, teachers and artefacts (Säljö, 2005).

\section{Scaffolding}

When learning is shaped by the social environment every person, has a larger extent of potential for learning than the definite capacity of the individual when learning is facilitated just by someone with larger knowledge (Wertsch, 1991). This range of a person's potential is called the zone of proximal development and is essential according to Vygotsky's ideas. Learning in the zone of proximal development is a combined activity in which the teacher simultaneously keeps an eye on the goals of the Learning design sequence and on what the student with assistance is capable to do.

Scaffolding is a strategy that teachers use to move learning forward in the zone of proximal development. It is a collaborative process. It involves negotiation of meaning between the teacher and the student about 
expectations and how to improve the learning process in the best way (Shepard, 2005). Examples of scaffolding could be when the teacher provides the student with different kinds of support e.g. hints encouragement, cognitive structures and reminders during the learning process through an LDS (Wood, Bruner \& Ross, 1976). One way of categorize scaffolding are Hill and Hannifin's (200I) four types of scaffolds; conceptual, metacognitive, procedural and strategic scaffolds. Conceptual scaffolds could be maps, outlines and clarifying examples which support the student to make choices about the selection or to prioritize what is important information. Metacognitive scaffolds may include reminders to reflect on the goal or a cognitive model, which helps the student to focus on the target or to estimate what he/she knows and what to do next in the learning process. Procedural scaffolds could be textual charts, graphic representations, site navigation maps or instructions about the working procedure which help the student to value resources and at the same time reduce the cognitive load in the procedure of navigation. Strategic scaffolds may include suggestions for alternative approaches to tackle a task that helps the student to develop an alternative perspective of an issue for example. Two categories which Hill and Hannafin don't include are the affective and the technical scaffolds which are found in Masters' and Yelland's research (2002). The affective scaffolding can consist of encouragement and praise. The technical scaffolding includes technical instruction and technical recovery in form of prompts or guiding questions to recover a technical mistake.

\section{Learning theories and factors that influence teacher interventions}

How do teachers intervene when pupils in Swedish schools use digital educational material? To answer this, we need to have a background to how we think learning occurs. According to Säljö (2005), there are three main learning traditions. The cognitive tradition, within which processes are more central than content, the subject didactic tradition, where content is of central importance and the socio cultural tradition, where people appropriate social experiences from situated activities. In this paper, we focus on the socio cultural description of learning.

In the Swedish curricula of 1994 (Skolverket, 1998) working methods must be democratic, with the students' participation in planning of activities and the teacher having a personal responsibility for the students' learning. The teacher should encourage independent as well as social work, including active learning, problem solving, communication and discussion. In Lpo 1994 (Skolverket, 1998) student learning is in centre of school activities, and this in turn impacts classroom strategies. Teaching strategies and daily classroom life are the most important points for student learning (Jedeskog, 2005). Interactive teaching is one way of teaching today. It includes active learning such as collaboration, communication and creation of meaning and understanding. Traditionally, in non-interactive teaching, the teacher is talking most of the time in the classroom. Interactive teaching on the other hand often supports social constructivist or socio-cultural learning. This includes being open for creative thinking, using challenging and open ended questions, encouraging group discussions and initiating more interaction, both between students and between teachers and students (English, Hargreaves and Hislam, 2002).

Teacher interventions are situated in a social context with deep historical and cultural traditions. Säljö (2005) means that institutions are units of social practice, having their own cultural tools. This includes communicative patterns and activities within special institutional frameworks. Different assumptions about the nature of learning are found within these institutions. We can talk about different physical, cognitive, communicative and historical contexts. Social structures have impact on individual actions and vice verse. People in the same social setting use common artefacts and common ways of communicating and acting.

We are also involved in a number of communities of practice. A community is defined by three dimensions: What it is about, how it functions and what capability it has produced. They share some common resources (such as routines, vocabulary and artifacts) which accumulate knowledge within the 
community. All members are involved in relationships which are important for learning (Lave and Wenger, 2003). Depending on academic subject, there are differences between how teachers plan and teach courses and approach ICT. According to Waggoner (1994), each subject has its own structure with given ontological and epistemological assumptions. We tend to teach as we are taught, and, since our teaching training varies between subjects, so does our teaching style. Santee and Siskin (1994) find that teachers have a deep identification with their subject. The teachers' perspectives on how they teach differ, and values are sometimes in conflict between subjects. In general, teachers within a subject share the same faith in who they are, what they are doing and how they would like to do it.

All of this, communities of practice, institutions, cultural tools and traditions, differences between teachers' subjects and their identification with their subject has impact on how teachers intervene in the classroom.

\section{Method}

The method and analysis we have employed is qualitative. According to our aim and research questions different methods of data collection are used, such as descriptive field observation, video recordings and interviews (formal and informal) with students as well as teachers. The material is gathered in classrooms when students use digital educational material in their daily work. It can for example consist of Internet, different software as Word, Power Point and Illustrator, Learning Management systems, digital cameras or scanners. The main part of the material consists of videotaped film. All material is not transcribed; instead we transcribe critical incidents (Tripp, 1993) which we choose according to the questions at issue. We have transcribed and analyzed different sequences according to our research questions. According to scientific practice we take responsibility for the research process being governed by ethical views, carried out in accordance with the ethical rules of the Swedish Research Council (http:/ /www.codex.vr.se/codex_eng/codex/index.html) for research in social science, including information requirement, approval requirement, confidentiality requirement and usage requirement.

\section{Scaffolding}

Concerning scaffolding the material is collected from three different schools and the students are 8 , 14 and 17 years old. we have analyzed the video material from the LDS model (see below) and Hill and Hannafin's four types of scaffolds; conceptual, metacognitive, procedural and strategic as well as Masters' and Yelland's (2002) two scaffolds: the affective and the technical. An example of conceptual scaffolds were clarifying examples from the teacher, a metacognitive scaffold could be a reminder from the teacher to reflect on the goal, graphic representations were examples of procedural scaffolds, a strategic scaffolds could consist of a question from the teacher which gave the student a different perspective of an issue, the affective scaffolding consisted mostly of encouragement and he technical scaffolding included technical instructions. The theme, and subject content of the three LDS's were for the 8-years old "The history of my life" in Swedish language, for the 14 years old "The travel through Europe" in home economics, social science, Music and ICT and for the upper secondary class it was "History of literature" in Swedish language. Regarding scaffolding, we also took our point of departure from the interviews.

\section{Teachers' interventions}

When it comes to teacher intervention the material is collected from two schools in two different classes, 13 and 14 years old students. The theme and subject content of the two LDS's were "Human existence, fears and children rights" for the 13 years old consisting Social Science, Music and ICT. According the 14 years old students it is the same material as scaffolding above with the theme "The travel to Europe" in Home economics, Social science, Music and ICT. The selection of sequences was delimited by the teacher coming to a group of students and intervening with them, and it lasts until 
the teacher has departed. The material will just allow us to analyze the sequences, not what has happened after that. The units of analysis were speech, activity, display, digital learning resource, which way the teacher comes to the group and the content of the intervention. We would like to point out that very rarely the analyzed sequences coincide with the analyzed sequences for scaffolding.

\section{The LDS model}

The analysis is also made according to the LDS model below. Within our research group we have constructed a model which we refer to as an LDS Learning Design Sequence. An LDS contains everything from the start of a learning sequence until the end, when students' work is finished, including presentations and assessment. It can be a two hour lesson in physics but also a long sequence in social studies which reaches over a whole semester. An LDS is framed by the institutional norms among the teachers and students the intentions in the curriculum and by the resources for learning which are available (left). It is also framed by the interest, group climate and patterns of social interactions (above). Focus in the model is how knowledge is created and reshaped in the process of learning. In the "Primary information resources for learning. In this cycle of information the students transform and form their knowledge of this information. What kind of media is used and which kind of information are shown in different modes. It is also interesting to how and in what way the group is a resource for learning. During this phase the teacher intervene in many ways. Then we have the "Second information unit" with is focus on the students representations and presenting. The students' discussion and reflection over their learning process and results are important in this phase. As you can see in the figure (below), teacher intervene during this unit too. Signs of learning are traced in the students' representations and in their process with new explanations and skills. The arrows inside the circle of the primary and secondary transformation unit symbolize a back and forward movement between transforming and forming knowledge in the primary unit, as well as represent and presenting knowledge in the secondary unit. During the primary and secondary transformation unit teacher intervene in many ways. One kind of intervention is assessment (below). In the primary transformation unit there is a focus on formative assessment and in the secondary a summative assessment (Selander, Engström, \& Åkerfeldt, 2007).

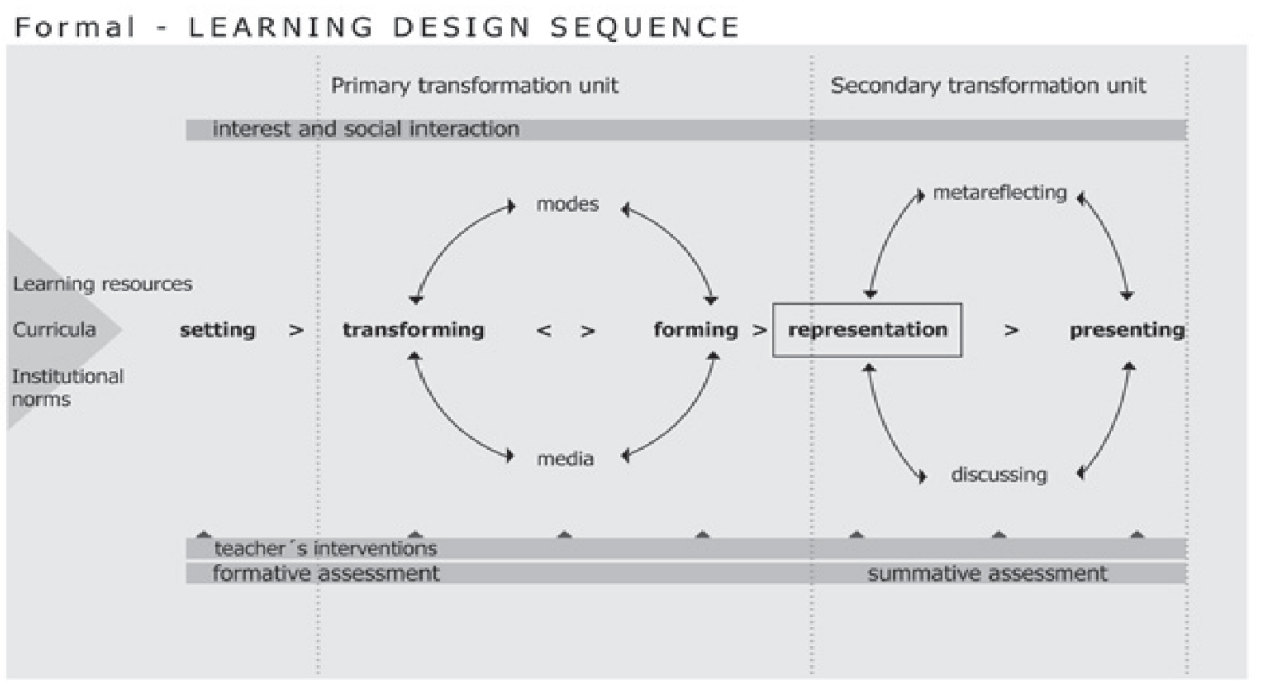

unit", the focus is on how student search for and process information, how they collaborate and interact with each other, with the teacher and
A teacher intervention can be observed before and during the primary transformation unit and through the secondary transformation unit of a Learning Design 
Unit. The teacher decides the content of an LDS, sometimes in collaboration with the students. There are many underlying processes which have an impact on learning in an LDS, such as intentions, curriculum, traditions, group climate and students' opportunities to reflect and represent the LDS. Scaffolding and teacher interventions occur in different ways along the whole LDS, from the start to the end. We have documented these sequences with a digital video camera and field observations. Interviews with both teachers and students take place after the Learning Design Sequence. Student's representations are gathered, sometimes as a CD, caught with our video cameras or in printed form.

In the research about scaffolding we videotaped one LDS each from three different schools in the suburbs of Stockholm. The students were 8, 14 and 17 years old. All the classes worked for about two months with their LDS. The video documentation consists of about 10 hours video recordings from each school. The LDS for the 8-years old students was called "History of my life" and included the school subject Swedish language. The students produced a PowerPoint slideshow about their life including text, pictures, photos and sound. One class, the 14-years old, was the same LDS as described down below as "The travel to Europe". The content of the third class' LDS was history of literature in an upper secondary school. The students and teachers used Internet and an LMS-system, software like PowerPoint, Illustrator and In Design. According to the LDS-model the units of analysis were; setting, primary transformations unittransforming information to forming learning and knowledge- and secondary transformation unit presenting and representing knowledge.

In the research about intervention we followed one LDS from each of two different schools. The students were 13 and 14 years old. Both of the LDSs which we followed involved thematic work with teachers from different subjects, lasting for almost a whole semester. One class had teachers in social science, music, ICT and home economics. The Learning Design Sequence was called "The travel to Europe". It was a storyline theme where the students learned about geography (climate, populations, industries, economy), cooking (inspired from a country in Europe), music (European composers) and science (European scientists) etc. The students pretended to be employed, with the goal of registering differences and similarities between European countries. They worked with computers (laptops and PCs) with various software (Power Point, Word, Internet) and digital cameras. A PowerPoint- production was presented as a result of the thematic work. The other class involved teachers in social science, ICT and music. Students worked with the Learning Design Sequence "Human existence, fears and children rights", using video cameras, digital photos and Apple computers with Movie and Garage Band. A movie about bullying and related topics was produced by the students based on interviews, filmed episodes and facts found from the Internet. As we can see in the LDS-model, teachers' interventions occur through the whole LDS, even before the primary transformation unit and secondary transformation unit. All the units in the LDS affect the teacher intervention and can be shown in the analyze of the results.

\section{Results and Discussion}

\section{Scaffolding}

Regarding all research questions about scaffolding the material is chosen from three different schools and three LDS'. The students are 8, 14 and 17 years old. In all three LDS' the teachers had organized the students' learning-process collaboratively in the social environment (Wertsch, 1991). The content and forms of learning were merged within collaborate thematic work where communication was important in the interdisciplinary activities (Lave \& Wenger, 2003; Säljö 2005). In all the three LDS' we found the learning-process organized first on a social level (Vygotsky, 1978) and then on a more individual level continuing to finish on a social level again. The results indicate that scaffolding was a strategy used by all the teachers to move learning forward in the zone of proximal development. We found forms as hints, encouragement, and cognitive reminders in all three classrooms both on social and individual level (Wood, 
Bruner \& Ross, 1976). All types of scaffolds (Hill \& Hannafin, 200I; Master \& Yelland, 2002) occurred in every part (setting, primary and secondary transformation unit) of an LDS. The most common type of scaffold was the procedural type (Hill \& Hannafin, 200I) in all the three LDS'. An example of that is when the teacher in advance has made an instruction sheet to help some of the students to value different resources on the Internet (below). She didn't use it for all students, some didn't need it, and this was one example for us to know that she was aware of the proximal zone of development of her students. The sheet consisted of the text below:

"There is a lot of information to get on the Internet, some is very good but some websites are not. Don't trust everything you read, see and listen to on the Internet! Be critical!

Choose your material from the Internet by using these questions below:

Who has made the website? Is it an authority, organization, a company or a private person?

Do they know a lot about the subject at issue? What purpose has the website?

To inform, to present facts, to advocate for something, to sell something or to entertain?

What do the website look like? Is there any contact information?

Does the text look serious to you? Do the hyperlinks work? Is there a date on the site?

Do they refer to other resources? Can you get information from other resources?

The library or trusted school sites? Have you compared this site with other websites?"

The most common phase where the scaffolds occurred was in the primary transformation unit when the students worked on their own or in group and the teacher's role was more of a guide than an instructor, an example of a collaborative process between the teacher and students where negotiation of meaning took place (Shepard, 2005). The technical scaffolds (Master \& Yelland, 2002) were more common in the setting and in the primary transformation unit than in the secondary in all three LDS's and they were more frequent among the younger students. In the upper secondary school different types of structures, such as how a story is structured or how to analyze a movie, were a common form of scaffolding. In this class we recognized that the students created their own structures in the working process and we interpret that scaffolding worked as a mediating resource for learning.

Concerning the second research question "Do students understand the same phenomena of scaffolding as teachers?" The results differ a lot between the schools. In one of them the teacher's view of scaffolding is quite similar to the students'. In another school the answers differ totally between the teacher and the students. For example in one case the teacher shows the learning goals for some pupils in order to be a metacognitive scaffold, a reminder to reflect on the goal and not continuing on a sidetrack (Hill \& Hannafin, 200I), but it is not at all comprehended as scaffolding by the pupils, as it were meant to be. The pupils we interviewed in this class considered scaffolding as instructions how to do things or direct answers from the teacher, answers which solved the problem the pupils themselves were set to solve. They didn't have the same view of how to learn as their teacher. In the third school the answers and the descriptions of scaffolding are very similar between the teacher and the students.

Regarding the third research question "Do students and teachers believe that schoolwork with digital educational material demands more, less or other kinds of scaffolding for learning?" we have used the interview material for analyzes as well. Among the younger students the teacher and the students agreed upon that schoolwork with digital education material demands more technical scaffolding (Master \& Yelland, 2002) to handle the digital artefact. The teacher also pointed out in the interviews that the pupils' thinking about the content is very much connected to the digital artefact (Säljö, 2005) in the interaction with it and the technical scaffold is therefore needed not only for technical matters. In another school the students express their increased need of conceptual scaffolding (Hill \& Hannafin, 200I) in the searching phase of the LDS. They express that it is more difficult to understand the information they get at the Internet compared with traditional 
educational material. The teacher in this school also thinks that it is necessary with more scaffolding to deepen the understanding for the students because it takes a lot of time to handle the artefact and get the technique working smoothly. The teacher in the third school thought more scaffolding is needed in form of metacognitive as well as procedural scaffolding (Hill \& Hannafin, 200I) since the information on the Internet is far more comprising than traditional educational material which requires more preparation from the teacher. The students were also of the opinion that working with Internet as a resource requires more cognitive scaffolds to help them to focus on the target.

To sum up most of the teachers and students, in this study, think that using digital educational material requires both more and other forms of scaffolding compared to other forms of educational material.

\section{Teachers' interventions}

The main questions for teachers' interventions in this study dealt with the focus and the content of the intervention, and if it supports or restricts the students' learning process. The analyze of the intervention was limited by the teacher coming to the students and lasted until de departure of the teachers. The results are strictly limited to these sequences. The results indicated that the focus of the teachers' interventions' were very important during both the "Primary information unit", and the "Second information unit" (Selander, Engström \& Åkerfeldt, 2007). The intention with the examples is to show how the focus of the intervention affects the learning process and make the intervention transparent. All LDS is framed by the institutional norms and patterns of social interactions (Selander, Engström \& Åkerfeldt, 2007), which become obvious in our observations. When it comes to teachers' interventions some of them occurred focusing directly towards the digital resources.

We are inside an eight's grade classroom. The mathematics- and ICT teacher Andrew walks around in the classroom, carrying a laptop. One of the boys, Daniel, calls for his attention and he steps forward to the boy's group that works around a table. They work with three laptops. Daniel: "Andrew, come now Andrew ... I get crazy on this computer."..."this strip, why is there empty space created when I try to paste copied material"... Then Andrew puts down his computer, leans forward, takes over the mouse from Daniel and looks into the screen. He starts working with Daniel's computer, and continues the work for a long time without involving Daniel at all. Daniel walks away, out in the classroom, and starts talking with other students... At last Daniel comes back and sits down, but he doesn't participate in Andrews work with Daniels computer... Andrew finishes saying "Well, now it works. That's it! Don't ask me what I did but now it works." Then the teacher grabs his own portable computer and walks away. This example shows a student calling for help and a male teacher coming. The digital learning resource is in focus and the teacher takes over. As a result, the student doesn't participate in problem solving and doesn't know what has happened, neither on his screen nor with his work. $\mathrm{He}$ is not told how to solve similar problems in the future. On the positive side, the student can resume his work after the teacher's support. This teacher intervenes as a technician, having a user support role.

When teachers teach ICT they often guide and instruct the students. The teacher intervention is focused on the ICT and a "how-to-do-it" perspective. The student is watching, being told what to do and then follows the instructions. The teacher is the guide that leads the student forward, which can be helpful in a learning situation. Two girls, Eve and Phoebe, work with one Macintosh computer each. An information and communications technology teacher gets to them and grabs the mouse. She demonstrates how to proceed and says: "Do like this ... I Movie works as follows, when you start a ... the movie appears ... that you need to put on your desktop". The student Eve says: "should we start then". The teacher is standing behind the two girls, helping one of them. When they start working she gives instructions by pointing at the screen. In this example the teacher is the guide who leads the students forward. She is supporting them to continue working. The teacher is both a technician and educator in this intervention. In the sociocultural perspective the artefact is central, 
and the students thinking is thought to be intimate connected to the artefacts they are using. The interaction between teachers, students and artefacts are closely connected to learning (Säljö, 2005). How teachers teach and interact with digital resources and students will have an impact on the learning process.

There are some examples of restricting the learning processes when the teacher interrupts ongoing activity. An example is when a teacher distracting students when the student group is deeply involved in writing a Power Point presentation. Their task is inspired by storyline and their work proceeds well, when a teacher comes and gives them test results from a test they did a couple of weeks earlier. Pat, social science-teacher of an eight's grade class steps forward to Adam and says: "Adam, I have corrected your essay about $X X X$ here". She opens the essay, gives it to Adam and reads her judgment. "Now I have corrected it and I actually liked it very well... you describe how he experiences all these events but $\ldots$ it would have required more analysis of causes and consequences ..." She puts down the essay in front of Adam and walks away. The student group leaves their writing and starts to talk about the test, shouting and asking other students in the classroom. This teacher action is obstructive since the students' work is interrupted. The result is that students loose interest in their work, discuss other things and become distracted. After this, the students can't find their way back to the working flow again, not even when the teacher has left.

We have examples where the contents of the work and interaction with the students are in focus, while the artefact is of secondary importance. In this example the teacher looks at the students more than on the computer screen. Daniel calls for Susan. "Susan! Can you read this?" The social science teacher gets around the table to Daniel, leans down and watches the screen...She reads through the contents. At the same time another student, Brad, finds something on the web. Susan to Daniel: “... what does lost searching mean?" Daniel: "It means that one walks around, out of the city..." Brad: "Ahh, check here... watch, the number of inhabitants in cities is $62 \%$." Susan to Brad: "Well, fine, then you got an answer to that question, that site is very good." She looks into the students' eyes while communicating with them. Susan points at Daniel's screen. Susan: "Have you found this at the same site too ..." Susan talks with Daniel and points at Brad. Brad takes part in the conversation and Susan laughs. She turns to everyone in the group. Susan: "You have chosen the black and red. Is that for any particular reason or?" Daniel: "No, it's just..." Susan talks and watches both Brad and Daniel. In this example, the teacher communicates with the whole group of students, asking questions and giving advice. The teacher is working as a facilitator engaging active learners. The teacher is encouraging group discussion and initiates more interaction to support learning. As a result, the students think together and collaborate, their views are widened and they are given different perspectives, everything situated. Whit in the activities they communicate which emphasis learning (Lave \& Wenger, 2003).

We have discovered a lot of interventions that focus on subject contents. When teachers intervene with a group, it is their subject skills that are in focus. The students will ask the social science teacher questions about social science, the ICT teacher ICTrelated questions and so on. An example of an intervention where the teacher has a subject oriented perspective is when a social science teacher comes to a student and discusses what GNP is, from her point of view the content in the work. Peter: "Kathy, here me". Peter calls for Kathy, the social science teacher who comes forward to him. She bends down, points at the screen and reads loudly: " . . this number exceeds 100 per cent... since more children than expected started school..." Peter wonders: "Should I just write 100 per cent?" Kathy: "Yes, you can do that... but have you copied this, will you have some sort of reasoning about it? ...Peter: "What does GNP mean?" Kathy: "It means Gross National Product ... then you will get a definition, the sum of all products and services..." During the whole conversation Peter gets back and forth between a PowerPoint presentation and the web. In this example, when the teachers reach a group, it is the teachers' subject skills that are in focus. Even though the activity is interdisciplinary, the interventions are not. The 
students ask the social science teacher questions about social science, the ICT-teacher about ICT-related questions and so on. The ICT teacher never comments on thematic contents, nor does the math and science teacher comment on social science work. Each teacher uses his or her particular subject skills. With this approach, each activity is defined within a certain subject or discipline. This teacher is a tutor that solves problems related to her subject matter. She is collaborating with the students and discussing problems. Challenging and open ended questions are used and the teacher is primarily an educator and facilitator for learning, using her subject authority to scaffold the student. The results indicate that the subject on one hand and the identification of the teacher's role with the subject on the other hand impact the behavior in the classroom. Teachers are formed and socialized into a community of practice with relationships and different teaching style. Their identification with their subjects is strong (Lave \& Wenger, 2003; Säljö, 2005; Waggoner, 1994; Santee \& Siskin, 1994). This was obvious in our video recordings when we saw how the teachers intervened with the students in a subject oriented way.

Also ICT can be taught in a subject oriented perspective. Lynn calls for the ICT teacher, called Anne, and says: "Anne, we have a small problem... we don't want to play the slide show so fast..." The speed of the slide show is considered as a problem. The teacher sits down by the computer, pointing at the screen. Changes of slides are discussed and the teacher informs all the time what is happening on the screen. Anne teaches about the changeover: “... when a change of slides has been completed, the film cut is locked and you can't work with it... Anne points at the screen and gesticulates, and then she looks at all three, one by one. She continues: "... is here at the rear side, for you to pull out...you may also double-click on this paper ..." Lynn answers with an "Aha!" Anne says "...I think you may elaborate a bit..." Anne points and instructs how to proceed. Lynn has the mouse and clicks where the teacher points at the screen. The teacher is interacting with the students and discussing the ICT content that are in focus in the discussion. The teacher is the link between the students and the computer and is both a technician and an educator in this intervention, trying to solve a technological educational issue. In these interventions we can see that teachers concentrate on ICT. For interventions concerning ICT there is a lot of guidance, with instructions leading the students forward.

\section{Conclusions}

The use of the LDS-model has helped us in the research group to see an LDS from various views that deepen and give a wider perspective on a learning process. In this paper it has been two different but related views that complement each other and the results can be fruitful in the understanding of the teachers work when digital resources are used in a learning environment.

Our conclusions about scaffolding are that it is used as a strategy by the teacher to move learning forward during all parts of an LDS when using digital educational material in school but it is needed even more (Shepard, 2005). Especially technical scaffolding (Masters \& Yelland, 2002) among the early users. In the beginning there is huge need of scaffolding to handle and learn (Säljö, 2000), by using the artefact so the students can be more independent and focus on the content and the task instead of technical matters. There is also a need of extended conceptual scaffolds (Hill \& Hannafin, 200 I) among older pupils using content from the Internet. Maybe the students use insufficient strategies to interpret and process information on the Internet? It is then even more important with more and different types of scaffolding in all phases of the learning process when they are working with Internet and digital educational material. We also found that the comprehension of scaffolding depends on the view on learning and knowledge. An example of that is when the teacher had prepared different types of scaffolding but the students didn't comprehend them at all as scaffolds because they considered learning as instructions or knowledge you get from the teacher. When the teacher didn't tell them exactly how to do, or didn't give them a direct answer to a question they didn't consider it as scaffolding. 
We have given some examples of teacher interventions during a Learning Design Sequence, where the teacher is either restrictive or supportive for the students' learning. In what directions is the teacher intervening? Is the focus on the students, artefact or the subject? Sometimes ICT becomes more of an object than a tool for teachers when software or hardware problems occur. Then they have to focus on ICT rather than encouraging more of student thinking related to their subject (Lim \& Hang, 2003). The consciousness from teachers how an intervention influences the learning is important, also to plan interdisciplinary work according to the results regarding the strong didactical influences when teachers' intervene. We want to continue the discussion how teachers intervene with digital artefacts and the students.

Our conclusions lead us to further questions. The teacher's role and how they intervene is is very important for learning but could the digital educational material be designed in another way including more scaffolds to complement the teacher's scaffolds? We could see that the teachers intervened in a way strongly influenced by the didactical tradition of teacher education for secondary teachers. Is that the reason why procedural scaffolds were the most common type of scaffold in all the LDSs? Do teachers need to teach more sufficient literacy strategies for learning when working with digital educational material? Do teachers need more competence development in the area of digital literacy?

\section{References}

English, E., Hargreaves, L., \& Hislam, J. (2002). Pedagogical Dilemmas in the National Literacy Strategy: primary teachers' perceptions, reflections and classroom behavior. Cambridge Journal of Education, 32(I), 9-26.

Hennessy, S., Ruthven, K., \& Brindley, S. (2005). Teacher perspectives on integrating ICT into subject teaching: commitment, constraints, and change. Journal of Curriculum Studies, 37(2), 155-192.
Hill, J., \& Hannafin, M. (200I) Teaching and learning in digital environments. The resurgence of resource-based learning. Educational Technology Research and Development, 49(3), 37-52.

Jedeskog, G. (2005). Ch@nging School. Implementation of ICT in Swedish School, Campaigns and Experiences 1984 - 2004. Uppsala: Uppsala Universitet Stryckeriet.

Lave, J., \& Wenger, E. (2003). Situated learning. Legitimate peripheral participation. Cambridge: Cambridge University Press.

Lim, C. P., \& Hang, D. (2003). An activity theory approach to research of ICT integration in Singapore schools. Pergamon. Computers and education, 4I, 49-63.

Masters, J., \& Yelland, N. (2002). Teacher scaffolding: An Exploration of Exemplary Practice. Education and information Technologies, 7(4), 3|3-32I.

Santee Siskin, L. (1994). Realms of knowledge: Academic Departments in Secondary Schools. Washington D.C: The Flamer Press.

Selander, A., Engström, S., \& Åkerfeldt, A. (2007) Resurser för lärande $i$ en digital miljöom 'Learning Design Sequences'. In Knudsen, Skjelbred og Aamotsbakken (Ed.), Tekst i vekst. Teoretiske, historiske og analytiske perspektiver på pedagogiske tekster. Oslo: Novus = o ns = "urn:schemas-microsoftcom:office:office" />

Shepard, L. A. (2005). Linking Formative Assessment to scaffolding. Educational leadership. November, 2005.

Skolverket (1998). Läroplan för det obligatoriska skolväsendet Lpo 94. The Swedish Research Council. [On-line]. http:// www.codex.vr.se/codex_eng/codex/index.html

Säljö, R. (2000). Lärande i praktiken. Stockholm: Prisma.

Säljö, R. (2005). Lärande och kulturella redskap. Om lärprocesser och det kollektiva minnet. Falun: Norstedts Akademiska Förlag.

Tripp, D. (1993). Critical incidents in teaching: developing professional judgement. London. Routledge.

Vygotsky, L. (1978). Mind in society. The development of higher psychological processes. Cambridge, MA: Harvard University Press.

Waggoner, M. (1994). Diciplinary Differences and the Integration of Technology into Teaching. Journal of Information Technology for Teacher Education, 3(2), 175- 186.

Wertsch, J. V. (199I). Voices of the mind: A sociocultural approach to mediated action. Cambridge, MA: Harvard University Press. 
Wood, D., Bruner, J. S., \& Ross, G. (1976). The role of tutoring problem solving. Journal of Child Psychology and Psychiatry, I7(2), 89- 100.

\section{Corresponding author:}

Eva Edman Stålbrandt and Annika Hössjer

Stockholm Institute of Education, Box 43103, S-100 26 Stockholm, Sweden E-mail:evaedm@lhs.se annhos@lhs.se 